Trauma Surgery \& Acute Care Open

\title{
American Association for the Surgery of Trauma emergency general surgery guideline summaries 2018: acute appendicitis, acute cholecystitis, acute diverticulitis, acute pancreatitis, and small bowel obstruction
}

\author{
Kevin M Schuster, ${ }^{1}$ Daniel N Holena, ${ }^{2}$ Ali Salim, ${ }^{3}$ Stephanie Savage, ${ }^{4}$ Marie Crandall ${ }^{5}$
}

'Department of Surgery, Yale University School of Medicine, New Haven, Connecticut, USA ${ }^{2}$ Department of Surgery, University of Pennsylvania, Perelman School of Medicine, Philadelphia, Pennsylvania, USA 'Division of Trauma, Burns and Surgical Critical Care, Brigham and Women's Hospital, Boston, Massachusetts, USA 4Indiana University Purdue University at Indianapolis, Indianapolis, Indiana, USA ${ }^{5}$ Department of Surgery, University of Florida College of Medicine-Jacksonville, Jacksonville, Florida, USA

Correspondence to Dr Marie Crandall, Surgery, University of Florida College of Medicine - Jacksonville, Jacksonville, FL 32209, USA marie.crandal|@jax.ufl.edu

Received 21 November 2018 Accepted 27 November 2018

(c) Author(s) (or their employer(s)) 2019. Re-use permitted under CC BY-NC. No commercial re-use. See rights and permissions. Published by BMJ.

To cite: Schuster KM, Holena DN, Salim A, et al. Trauma Surg Acute Care Open 2019:4:e00281.

\section{ABSTRACT}

In April 2017, the American Association for the Surgery of Trauma (AAST) asked the AAST Patient Assessment Committee to undertake a gap analysis for published clinical practice guidelines in emergency general surgery (EGS). Committee members performed literature searches to catalogue published guidelines for common EGS diseases and also to identify gaps in the literature where guidelines could be created. For five of the most common EGS conditions, acute appendicitis, acute cholecystitis, acute diverticulitis, acute pancreatitis, and small bowel obstruction, we found multiple well-referenced guidelines published by leading professional organizations. We have summarized guideline recommendations for each of these disease states stratified by the AAST EGS anatomic severity score based on these published consensus guidelines. These summaries could be used to help inform evidencebased clinical decision-making, but are intended to be flexible and updatable in real time as further research emerges. Comprehensive guidelines were available for all of the diseases queried and identified gaps most commonly represented areas lacking a solid evidence base. These are therefore areas where further research is needed.

\section{ACUTE APPENDICITIS MANAGEMENT GUIDELINES SUMMARY}

Multiple societies have published guidelines for the diagnosis and management of appendicitis. Notably, a consensus statement was published in Surgical Endoscopy in 2015, and a summary from the World Society of Emergency Surgery was published in the World Journal of Emergency Surgery in 2016. Several other comprehensive guidelines covering imaging recommendations, antimicrobial prophylaxis and duration, laparoscopic versus open surgical approach, and optimal management of perforated appendicitis have been published. This review summarizes and references evidence-based guidelines for appendicitis by stage, as a reference guide for surgeons practicing emergency general surgery.

\begin{tabular}{|c|c|c|c|}
\hline $\begin{array}{l}\text { American } \\
\text { Association } \\
\text { for the } \\
\text { Surgery } \\
\text { of Trauma } \\
\text { grade }\end{array}$ & Description & Management & References \\
\hline I & $\begin{array}{l}\text { Acutely inflamed } \\
\text { appendix, intact }\end{array}$ & $\begin{array}{l}\text { Laparoscopic } \\
\text { appendectomy } \\
\text { Non-operative } \\
\text { therapy with } \\
\text { antibiotics } \\
\text { may be a } \\
\text { reasonable } \\
\text { alternative } \\
\text { No } \\
\text { postoperative } \\
\text { antibiotics } \\
\text { are indicated } \\
\text { in surgically } \\
\text { managed } \\
\text { appendicitis }\end{array}$ & $\begin{array}{l}123467 \\
3 \\
2\end{array}$ \\
\hline II & $\begin{array}{l}\text { Gangrenous } \\
\text { appendix, intact }\end{array}$ & $\begin{array}{l}\text { Laparoscopic } \\
\text { appendectomy }\end{array}$ & 123467 \\
\hline III & $\begin{array}{l}\text { Perforated } \\
\text { appendix } \\
\text { with local } \\
\text { contamination }\end{array}$ & $\begin{array}{l}\text { Laparoscopic } \\
\text { appendectomy }\end{array}$ & 123467 \\
\hline IV & $\begin{array}{l}\text { Perforated } \\
\text { appendix with } \\
\text { periappendiceal } \\
\text { phlegmon or } \\
\text { abscess }\end{array}$ & $\begin{array}{l}\text { Laparoscopic } \\
\text { appendectomy } \\
\text { Non-operative } \\
\text { therapy with } \\
\text { antibiotics may } \\
\text { be chosen in } \\
\text { select patients }\end{array}$ & $\begin{array}{l}123467 \\
3\end{array}$ \\
\hline V & $\begin{array}{l}\text { Perforated } \\
\text { appendix with } \\
\text { generalized } \\
\text { peritonitis }\end{array}$ & $\begin{array}{l}\text { Laparoscopic } \\
\text { appendectomy } \\
\text { when feasible }\end{array}$ & 123467 \\
\hline
\end{tabular}

Key points

Laparoscopic appendectomy is considered the gold standard for acute appendicitis and should be the procedure of choice, except when laparoscopy is contraindicated or not feasible. Studies have demonstrated the laparoscopic approach is equivalent to, or better than, the open technique in most circumstances. Conversion to open may be necessary in technically difficult cases, however. Laparoscopic appendectomy is safe in the obese, elderly patients, pediatric patients and pregnant patient populations, including in the third trimester. ${ }^{1,2,3,4,6,7}$ 
Non-operative therapy is a reasonable approach in uncomplicated acute appendicitis. Patients should be educated that the possibility of recurrence exists. Non-operative therapy may also be considered in some cases of acute appendicitis with phlegmon or abscess. ${ }^{3}$ In most other situations, appendectomy is the standard of care.

CT imaging is more reliable that ultrasound for the diagnosis of acute appendicitis. The use of intravenous contrast may improve the sensitivity of this test and is generally recommended when CT imaging is performed. Exceptions to CT may be pursued in pregnant women and children to minimize exposure to radiation. Ultrasound is preferred for diagnosis in pregnant patients and children. If ultrasound is equivocal, MRI would be the next diagnostic test of choice. ${ }^{2,3,5,8}$

Preoperative antibiotics should be administered as soon as the diagnosis of acute appendicitis is made. There is no indication for postoperative antibiotics in uncomplicated appendicitis. ${ }^{2}$ There are also no data supporting improvement in clinical outcomes with any given scoring system for acute appendicitis.

Technical maneuvers, such as peritoneal irrigation, variations in appendiceal stump closure or methods of mesenteric vascular control have demonstrated no difference in outcomes. ${ }^{3}$

Contributors KMS and MC conceived this manuscript and performed the final edits. All authors performed the literature reviews and guideline summary statements, authored and edited the summary statements.

Competing interests None declared.

Patient consent for publication Not required.

Provenance and peer review Commissioned; internally peer reviewed.

Open access This is an open access article distributed in accordance with the Creative Commons Attribution Non Commercial (CC BY-NC 4.0) license, which permits others to distribute, remix, adapt, build upon this work non-commercially, and license their derivative works on different terms, provided the original work is properly cited, appropriate credit is given, any changes made indicated, and the use is non-commercial. See: http://creativecommons.org/licenses/by-nc/4.0/.

\section{REFERENCES}

1. Sauerland S, Lefering R, Neugebauer EA. Laparoscopic versus open surgery for suspected appendicitis. Cochrane Database Syst Rev 2002:CD001546.

2. Gorter RR, Eker HH, Gorter-Stam MA, Abis GS, Acharya A, Ankersmit M, Antoniou SA, Arolfo S, Babic B, Boni L, et al. Diagnosis and management of acute appendicitis. EAES consensus development conference 2015. Surg Endosc 2016;30:4668-90.

3. Di Saverio S, Birindelli A, Kelly MD, Catena F, Weber DG, Sartelli M, Sugrue M, De Moya M, Gomes CA, Bhangu A, et al. WSES Jerusalem guidelines for diagnosis and treatment of acute appendicitis. World J Emerg Surg 2016;11:34.

4. Vettoretto N, Gobbi S, Corradi A, Belli F, Piccolo D, Pernazza G, Mannino L. Consensus Conference on laparoscopic appendectomy: development of guidelines. Colorectal Dis 2011:;13:748-54.

5. Howell JM, Eddy OL, Lukens TW, Thiessen ME, Weingart SD, Decker WW. Clinical policy: critical issues in the evaluation and management of emergency department patients with suspected appendicitis. Ann Emerg Med 2010;55:71-116.

6. Korndorffer JR, Fellinger E, Reed W. SAGES guideline for laparoscopic appendectomy. Surg Endosc 2010;24:757-61.

7. IPEG Standard and Safety Committee. IPEG guidelines for appendectomy. J Laparoendosc Adv Surg Tech A 2009;19(s1):vii-ix.

8. NGC:010146 American College of Radiology ACR Appropriateness Criteria $®$ right lower quadrant pain — suspected appendicitis. https://www.guideline.gov/summaries/summary/ 47652/acr-appropriateness-criteria--right-lower-quadrant-pain---suspected-appendicitis?q= appendicitis

\section{ACUTE CHOLECYSTITIS MANAGEMENT GUIDELINES SUMMARY}

Hepaticopancreaticobiliary conditions comprise up to $26 \%$ of emergency general surgery (EGS) admissions, of which $40 \%$ require an operation. ${ }^{1}$ In 2012, acute calculus cholecystitis was the second most common gastrointestinal reason for hospital admission, resulting in over 225000 hospital admissions. ${ }^{2}$ Gallstones occur in $10 \%-15 \%$ of the adult population, of whom $80 \%$ are asymptomatic. Acute cholecystitis develops in $1 \%-3 \%$ of patients with symptomatic gallstones ${ }^{3}$ and occurs most frequently in patients aged 18-44. There is a predominance in females (86 cases per 10000 discharges in women compared with 65 per 10000 discharges in men) and the incidence and hospital costs associated with acute cholecystitis appear to be rising. ${ }^{4}$

There are multiple published guidelines related acute cholecystitis focusing on diagnosis, management, and timing of surgical therapy. Of these, the most prominent are the Tokyo Guidelines (published in $2007^{5}$ with updates in $2013^{6}$ and subsequently updated in 2018) ${ }^{7}$ which include a severity grading for acute cholecystitis. As with several other common EGS disease states, the American Association for the Surgery of Trauma (AAST) has developed a grading system for acute cholecystitis that addresses clinical, radiologic, operative and pathologic features of acute cholecystitis and which has recently been validated in the literature. $^{8}$ The recommendations in this review are based on guidelines put forth by organizations whose mission includes the advancement of research and clinical care for patients with cholecystitis, but the underlying literature supporting these guidelines is heterogenous with respect to inclusion criteria and definitions of exposures and outcomes. Notably, because this literature predates the publication of AAST severity grades for acute cholecystitis, the way in which these guidelines pertain to specific AAST grades of acute cholecystitis requires further investigation.

\begin{tabular}{|c|c|c|c|c|}
\hline Grade & $\begin{array}{l}\text { AAST disease } \\
\text { grade }\end{array}$ & $\begin{array}{l}\text { Corres- } \\
\text { ponding } \\
\text { Tokyo grade }\end{array}$ & Management & $\begin{array}{l}\text { Ref- } \\
\text { erences }\end{array}$ \\
\hline I & $\begin{array}{l}\text { Local disease; } \\
\text { confined to the } \\
\text { organ; } \\
\text { minimal } \\
\text { abnormality }\end{array}$ & 1 & $\begin{array}{l}\text { Operative (laparoscopic if } \\
\text { possible) if within } 10 \text { days of } \\
\text { onset of symptoms; consider } \\
\text { antibiotics } \pm \text { percutaneous } \\
\text { cholecystostomy tube if } \\
\text { beyond } 10 \text { days }\end{array}$ & 791011 \\
\hline II & $\begin{array}{l}\text { Local disease; } \\
\text { confined to the } \\
\text { organ; } \\
\text { severe } \\
\text { abnormality }\end{array}$ & II & $\begin{array}{l}\text { Operative (laparoscopic if } \\
\text { possible; consideration of } \\
\text { conversion to open/subtotal } \\
\text { cholecystectomy as dictated } \\
\text { by intraoperative findings); } \\
\text { antibiotics and percutaneous } \\
\text { cholecystostomy tube may be } \\
\text { considered, but evidentiary } \\
\text { support for populations } \\
\text { who may benefit from this } \\
\text { approach is sparse }\end{array}$ & $7910-12$ \\
\hline III & $\begin{array}{l}\text { Beyond the } \\
\text { organ; } \\
\text { locally advanced } \\
\text { only }\end{array}$ & ॥ & $\begin{array}{l}\text { Operative (laparoscopic if } \\
\text { possible; consideration of } \\
\text { conversion to open/subtotal } \\
\text { cholecystectomy as dictated } \\
\text { by intraoperative findings); } \\
\text { antibiotics and percutaneous } \\
\text { cholecystostomy tube may be } \\
\text { considered, but evidentiary } \\
\text { support for populations } \\
\text { who may benefit from this } \\
\text { approach is sparse }\end{array}$ & $7910-12$ \\
\hline IV & $\begin{array}{l}\text { Beyond the } \\
\text { organ; } \\
\text { regional } \\
\text { extension }\end{array}$ & II & $\begin{array}{l}\text { Operative (laparoscopic if } \\
\text { possible; consideration of } \\
\text { conversion to open/subtotal } \\
\text { cholecystectomy as dictated } \\
\text { by intraoperative findings) }\end{array}$ & $7910-12$ \\
\hline V & $\begin{array}{l}\text { Beyond the } \\
\text { organ; } \\
\text { widespread } \\
\text { involvement }\end{array}$ & III & $\begin{array}{l}\text { Operative (laparoscopic } \\
\text { if possible; consideration } \\
\text { of open approach in the } \\
\text { setting of septic shock; } \\
\text { strong consideration of } \\
\text { conversion to open/subtotal } \\
\text { cholecystectomy as dictated } \\
\text { by intraoperative findings) }\end{array}$ & $7910-12$ \\
\hline
\end{tabular}




\section{KEY POINTS}

Cholecystectomy is the gold standard for treatment of acute calculous cholecystitis (ACC). ${ }^{9}$ Clinical outcomes for surgery are superior to observation in ACC and shows some cost-effectiveness advantages-due to gallstone-related complications and high rates of readmission and surgery in the observation group. ${ }^{1314}$

Laparoscopic cholecystectomy is recommended over open cholecystectomy in ACC. ${ }^{10} 11$ 15 Among high-risk patients, in those with Child A and B cirrhosis, ${ }^{16}$ advanced age $>80,{ }^{17}$ or pregnant women, ${ }^{18}$ laparoscopic cholecystectomy for ACC is feasible and safe. A laparoscopic approach should initially be attempted except in case of absolute anesthesiology contraindications or septic shock. ${ }^{15}$

Laparoscopic or open subtotal cholecystectomy is a valid option for advanced inflammation, gangrenous gallbladder, or any setting of the 'difficult gallbladder' where anatomy is difficult to recognize and main bile duct injuries are more likely. ${ }^{12}$

Although the definition of early versus late surgery varies by study, in general early laparoscopic cholecystectomy is preferable to delayed laparoscopic cholecystectomy in patients with ACC as long as it is completed within 10 days of onset of symptoms. ${ }^{1920}$ Laparoscopic cholecystectomy should not be offered for patients beyond 10 days from the onset of symptoms unless symptoms suggestive of worsening peritonitis or sepsis warrant an emergency surgical intervention. In people with more than 10 days of symptoms, delaying cholecystectomy for 45 days is better than immediate surgery. ${ }^{21}$

Antibiotics should be suggested as supportive care; they are effective in treating the first episode of ACC, but a high rate of relapse can be expected. Surgery is more effective than antibiotics alone in the treatment of ACC. ${ }^{1922}$ Patients with uncomplicated cholecystitis can be treated without postoperative antibiotics when the focus of infection is controlled by cholecystectomy. ${ }^{23}$

Percutaneous cholecystostomy could be considered as a possible alternative to surgery after the failure of conservative treatment in a small subset of patients unfit for emergency surgery due to their severe comorbidities. ${ }^{9}$ There are no reports providing quality scientific evidence on the best timing for surgery after percutaneous cholecystostomy, so a consensus has not been reached. ${ }^{24}$

\section{AREAS OF ONGOING RESEARCH}

Several guidelines suggest considerations for estimation of perioperative risk in ACC, but there is currently no consensus as to the most accurate and reliable method of risk stratification. Future works should focus on a generalizable and approachable method of identifying high-risk patients.

Use of percutaneous cholecystostomy tubes in patients at elevated risk for surgery appears to be increasing, but the indications for this procedure and the optimal management thereafter are not well defined. Future investigations should help address these knowledge gaps.

\section{REFERENCES}

1. Gale SC, Shafi S, Dombrovskiy VY, Arumugam D, Crystal JS. The public health burden of emergency general surgery in the United States: A 10-year analysis of the Nationwide Inpatient Sample--2001 to 2010. J Trauma Acute Care Surg 2014;77:202-8.

2. Peery AF, Dellon ES, Lund J, Crockett SD, McGowan CE, Bulsiewicz WJ, Gangarosa LM, Thiny MT, Stizenberg K, Morgan DR, et al. Burden of gastrointestinal disease in the United States: 2012 update. Gastroenterology 2012;143:1179-87.

3. Friedman GD. Natural history of asymptomatic and symptomatic gallstones. Am J Surg 1993;165:399-404
4. Wadhwa V, Jobanputra Y, Garg SK, Patwardhan S, Mehta D, Sanaka MR. Nationwide trends of hospital admissions for acute cholecystitis in the United States. Gastroenterol Rep 2017;5:36-42.

5. Tokyo Guidelines for the management of acute cholangitis and cholecystitis. Proceedings of a consensus meeting, April 2006, Tokyo, Japan. J Hepatobiliary Pancreat Surg 2007;14:1-121.

6. Yokoe M, Takada T, Strasberg SM, Solomkin JS, Mayumi T, Gomi H, Pitt HA, Garden OJ, Kiriyama S, Hata J, et al. TG13 diagnostic criteria and severity grading of acute cholecystitis (with videos). J Hepatobiliary Pancreat Sci 2013;20:35-46.

1_7.0kamoto K, Suzuki K, Takada T, et al. Tokyo guidelines 2018: flowchart for the management of acute cholecystitis. J Hepatobiliary Pancreat Sci 2017.

8. Vera K, Pei KY, Schuster KM, Davis KA. Validation of a new American Association for the surgery of trauma (AAST) anatomic severity grading system for acute cholecystitis. J Trauma Acute Care Surg 2018;84:650-4.

9. Ansaloni L, Pisano M, Coccolini F, Peitzmann AB, Fingerhut A, Catena F, Agresta F, Allegri A, Bailey I, Balogh ZJ, et al. 2016 WSES guidelines on acute calculous cholecystitis. World J Emerg Surg 2016;11:25.

10. Keus F, de Jong J, Gooszen HG, Laarhoven CJHM, Van Laarhoven C. Laparoscopic versus open cholecystectomy for patients with symptomatic cholecystolithiasis. Cochrane Database Syst Rev 2006;80(Suppl).

11. Kiviluoto T, Sirén J, Luukkonen P, Kivilaakso E. Randomised trial of laparoscopic versus open cholecystectomy for acute and gangrenous cholecystitis. The Lancet 1998;351:321-5.

12. Elshaer M, Gravante G, Thomas K, Sorge R, Al-Hamali S, Ebdewi H. Subtotal cholecystectomy for "difficult gallbladders": systematic review and meta-analysis. JAMA Surg 2015;150:159-68.

13. Brazzelli M, Cruickshank M, Kilonzo M, Ahmed I, Stewart F, McNamee P, Elders A, Fraser C, Avenell A, Ramsay C, et al. Clinical effectiveness and cost-effectiveness of cholecystectomy compared with observation/conservative management for preventing recurrent symptoms and complications in adults presenting with uncomplicated symptomatic gallstones or cholecystitis: a systematic review and economic evaluation. Health Technol Assess 2014;18:1-102.

14. Schmidt M, Søndenaa K, Vetrhus M, Berhane T, Eide GE. A randomized controlled study of uncomplicated gallstone disease with a 14-year follow-up showed that operation was the preferred treatment. Dig Surg 2011;28:270-6.

15. Yamashita Y, Takada T, Strasberg SM, Pitt HA, Gouma DJ, Garden OJ, Büchler MW, Gomi H, Dervenis C, Windsor JA, et al. TG13 surgical management of acute cholecystitis. J Hepatobiliary Pancreat Sci 2013;20:89-96.

16. de Goede B, Klitsie PJ, Hagen SM, van Kempen BJ, Spronk S, Metselaar HJ, Lange JF, Kazemier G. Meta-analysis of laparoscopic versus open cholecystectomy for patients with liver cirrhosis and symptomatic cholecystolithiasis. Br J Surg 2013;100:209-16.

17. Peker $Y$, Ünalp HR, Durak E, et al. Laparoscopic cholecystectomy in patients aged 80 years and older: an analysis of 111 patients. Surgical Laparoscopy, Endoscopy and Percutaneous Techniques 2014:24:173-6.

18. Catani M, De Milito R, Romagnoli F, Silvestri V, Usai V, Modini C. Laparoscopic approach to the acute cholecystitis in pregnancy. 2010.

19. Gurusamy KS, Davidson C, Gluud C, Davidson BR. Early versus delayed laparoscopic cholecystectomy for people with acute cholecystitis. The Cochrane database of systematic reviews 2013;6.

20. Gurusamy K, Samraj K, Gluud C, Wilson E, Davidson BR. Meta-analysis of randomized controlled trials on the safety and effectiveness of early versus delayed laparoscopic cholecystectomy for acute cholecystitis. Br I Surg 2010;97:141-50.

21. Gutt CN, Encke J, Köninger J, Harnoss JC, Weigand K, Kipfmüller K, Schunter O, Götze T, Golling MT, Menges M, et al. Acute cholecystitis: early versus delayed cholecystectomy, a multicenter randomized trial (ACDC study, NCT00447304). Ann Surg 2013;258:385-91

22. Papi C, Catarci M, D'Ambrosio L, Gili L, Koch M, Grassi GB, Capurso L. Timing of cholecystectomy for acute calculous cholecystitis: a meta-analysis. Am I Gastroenterol 2004:99:147-55

23. Regimbeau JM, Fuks D, Pautrat K, Mauvais F, Haccart V, Msika S, Mathonnet M, Scotté M, Paquet JC, Vons C, et al. Effect of postoperative antibiotic administration on postoperative infection following cholecystectomy for acute calculous cholecystitis: a randomized clinical trial. JAMA 2014;312:145-54.

24. Gurusamy KS, Rossi M, Davidson BR. Percutaneous cholecystostomy for high-risk surgical patients with acute calculous cholecystitis. Cochrane Database Syst Rev 2013;15.

\section{ACUTE COLONIC DIVERTICULITIS MANAGEMENT GUIDELINES SUMMARY}

Acute colonic diverticulitis is the sixth most common gastrointestinal diagnosis and represents a significant burden of disease. ${ }^{1}$ Between 2000 and 2009, admissions for diverticulitis increased 41\%, representing over 219000 discharges and US\$2.1 billion dollars in inpatient charges. ${ }^{2}$ As the population ages, these numbers are likely to increase, since at least $60 \%$ of people over 
the age of 60 have diverticulosis and $10 \%-25 \%$ will progress to diverticulitis at some point. ${ }^{2-3}$ Though $85 \%$ of these episodes are likely to be uncomplicated, 15\%-30\% will experience at least one recurrence. ${ }^{3}$

Diverticulitis may occur at any age. Factors associated with diverticulitis include a low-fiber diet and a sedentary lifestyle leading to obesity. ${ }^{4}$ The initial episode has the highest association with need for surgical therapy, as scarring related to these episodes is though to make perforation with subsequent episodes less likely. ${ }^{1}$ Complicated diverticulitis is associated with smoking, non-steroidal anti-inflammatory drug use, organ transplantation and steroid use. ${ }^{2,4}$

The American Association for the Surgery of Trauma (AAST) has developed a grading system for diverticulitis that addresses clinical, radiologic, operative and pathologic grades of disease. This system has been validated in the literature. ${ }^{5}$ This addresses noted gaps of current grading systems, such as those inherent in the original Hinchey system or the Ambrosetti CT classification. ${ }^{4,-8}$ Recommendations regarding the management of diverticulitis are based on a combination of expert consensus and research. Overall, quality of the research is mixed, with many studies suffering from small numbers and issues with bias.

\begin{tabular}{|c|c|c|c|c|}
\hline Grade & $\begin{array}{l}\text { AAST } \\
\text { disease } \\
\text { grade }\end{array}$ & $\begin{array}{l}\text { Corres- } \\
\text { ponding } \\
\text { Hinchey } \\
\text { grade }\end{array}$ & Management & References \\
\hline | & $\begin{array}{l}\text { Local } \\
\text { disease; } \\
\text { confined to } \\
\text { the organ; } \\
\text { minimal } \\
\text { abnormality }\end{array}$ & $\mathrm{N} / \mathrm{A}, \mathrm{O}$ & $\begin{array}{l}\text { Outpatient care } \\
\text { Selective antibiotics }\end{array}$ & $\begin{array}{l}2349101114 \\
34911\end{array}$ \\
\hline II & $\begin{array}{l}\text { Local } \\
\text { disease; } \\
\text { confined to } \\
\text { the organ; } \\
\text { severe } \\
\text { abnormality }\end{array}$ & $I, I$ & $\begin{array}{l}\text { Outpatient care } \\
\text { Selective antibiotics }\end{array}$ & $\begin{array}{l}2349101114 \\
34911\end{array}$ \\
\hline III & $\begin{array}{l}\text { Beyond the } \\
\text { organ; } \\
\text { locally } \\
\text { advanced } \\
\text { only }\end{array}$ & I, II & $\begin{array}{l}\text { Antibiotics } \pm \text { percutaneous } \\
\text { drainage }\end{array}$ & 3491011 \\
\hline IV & $\begin{array}{l}\text { Beyond the } \\
\text { organ; } \\
\text { regional } \\
\text { extension }\end{array}$ & II, III & $\begin{array}{l}\text { Antibiotics } \pm \text { percutaneous } \\
\text { drainage }\end{array}$ & 3491011 \\
\hline V & $\begin{array}{l}\text { Beyond the } \\
\text { organ; } \\
\text { widespread } \\
\text { involvement }\end{array}$ & III, IV, IV & $\begin{array}{l}\text { Resection with stoma } \\
\text { Selected single-stage } \\
\text { operations }\end{array}$ & $\begin{array}{l}34911 \\
34791011\end{array}$ \\
\hline
\end{tabular}

\section{KEY POINTS}

For the management of uncomplicated diverticulitis (grades 1 and 2), it is safe and reasonable to manage as antpatient in otherwise healthy patients. 2, 3, 4, 9, 10,11

Routine use of antibiotics is currently the standard of care and is successful in 90\% of cases of grades 1 and 2 diverticulitis. Recent literature has indicated that a more selective use of antibiotics, individualized to the patient's clinical state, is preferable. Antibiotics have not been shown to decrease the severity or duration of symptoms and may be associated with allergic reaction and resistance. ${ }^{3,4,9,11}$

There are no data to support avoiding seeds, nuts or corn, or other dietary restrictions as a means to avoid recurrent diverticulitis. Data is mixed regarding the role of dietary fiber in preventing recurrent disease. Overall, increased vigorous activity is supported, though the exact role between activity and recurrent diverticulitis is unclear. $4,9,10$

In grades 3 and 4 diverticulitis, a contained abscess may be treated with antibiotics if small, or percutaneous drainage and antibiotics if larger, as long as there are no other indications for surgery. ${ }^{3,4,9,10,11}$

During the last decade, attempts have been made to treat grade 3-5 diverticulitis with laparoscopic washout. Multiple trials in Europe, including the laparoscopic lavage (LOLA) trial, the Scandinavian Diverticulitis trial and DIVER (Outpatient versus hospitalization management for uncomplicated diverticulitis) trial found increased need for subsequent operations in patients undergoing laparoscopic peritoneal lavage. Laparoscopic lavage is no longer supported in the treatment of acute diverticulitis. ${ }^{12,13}$

The gold-standard remains exploratory laparotomy with resection for fecal peritonitis. A two-stage procedure (Hartmann's) is still the most commonly performed surgery in the setting of acute inflammation. 3, 4,9,11 A growing body of literature supports primary anastomosis, with or without a diverting loop ileostomy, in carefully selected patients. ${ }^{3,4,7,9,10,11}$

Evidence regarding the role of colonoscopy screening after acute diverticulitis is mixed. In symptomatic patients, screening colonoscopy is still recommended. In asymptomatic patients, who are compliant with a standard screening schedule, additional colonoscopy is likely not warranted and low yield. 1,3, 4, 9, 10,11

Elective colonic resection after the second episode of acute colonic diverticulitis is no longer recommended. The decision for surgery should be individualized to the patient. Laparoscopic approaches are recommended where possible to decrease post-operative risk of small bowel obstruction and post-operative hernia. ${ }^{9}, 10$

\section{Areas of ongoing research}

Immunocompromised patients, including those who have had solid organ transplants or who take chronic steroids, are a special population. Earlier operative intervention, with a more conservative staged approach, may be warranted.

Duration of antibiotic therapy is still not standardized. An individualized, patient-based approach is still the preferred approach.

\section{REFERENCES}

1. Ambrosetti P, Gervaz P. Management of sigmoid diverticulitis: an update. Updates Surg 2016:68:25-35.

2. Bollom A, Austrie J, Hirsch W, Nee J, Friedlander D, Ellingson K, Cheng V, Lembo A. Emergency department burden of diverticulitis in the USA, 2006-2013. Dig Dis SCi 2017:62:2694-703.

3. Shah SD, Cifu AS. Management of acute diverticulitis. JAMA 2017;318:291-2.

4. Vennix S, Morton DG, Hahnloser D, Lange JF, Bemelman WA. Systematic review of evidence and consensus on diverticulitis: an analysis of national and international guidelines. Colorectal Dis 2014;16:866-78.

2_5.Shafi S, Priest EL, Crandall ML, Klekar CS, Nazim A, Aboutanos M, Agarwal S, Bhattacharya B, Byrge N, Dhillon TS, et al. Multicenter validation of American Association for the surgery of trauma grading system for acute colonic diverticulitis and its use for emergency general surgery quality improvement program. J Trauma Acute Care Surg 2016;80:405-11.

6. Hinchey EJ, Schaal PG, Richards GK. Treatment of perforated diverticular disease of the colon. Adv Surg 1978;12:85-109.

7. Wasvary H, Turfah F, Kadro O, Beauregard W. Same hospitalization resection for acute diverticulitis. Am Surg 1999:65:632-5

8. Ambrosetti P, Grossholz M, Becker C, Terrier F, Morel P. Computed tomography in acute left colonic diverticulitis. Br J Surg 1997:84:532-4.

9. Boermeester MA, Humes DJ, Velmahos GC, Søreide K. Contemporary review of riskstratified management in acute uncomplicated and complicated diverticulitis. World J Surg 2016;40:2537-45

10. Horesh N, Wasserberg N, Zbar AP, Gravetz A, Berger Y, Gutman M, Rosin D, Zmora O. Changing paradigms in the management of diverticulitis. Int J Surg 2016;33(Pt A):146-50. 
11. Stollman N, Smalley W, Hirano I, Adams MA, Dorn SD, Dudley-Brown SL, Flamm SL, Gellad ZF, Gruss CB, Kosinski LR. AGA Institute Clinical Guidelines Committee. American gastroenterological association Institute guideline on the management of acute diverticulitis. Gastroenterology 2015;149:1944-9.

12. Vennix S, Musters GD, Mulder IM, Swank HA, Consten EC, Belgers EH, van Geloven AA, Gerhards MF, Govaert MJ, van Grevenstein WM, et al. Laparoscopic peritoneal lavage or sigmoidectomy for perforated diverticulitis with purulent peritonitis: a multicentre, parallel-group, randomised, open-label trial. The Lancet 2015;386:1269-77.

13. Schultz JK, Yaqub S, Wallon C, Blecic L, Forsmo HM, Folkesson J, Buchwald P, Körner $\mathrm{H}$, Dahl FA, Øresland T. Laparoscopic lavage vs primary resection for acute perforated diverticulitis. JAMA 2015;314:1364-75.

14. Biondo S, Golda T, Kreisler E, Espin E, Vallribera F, Oteiza F, Codina-Cazador A, Pujadas M, Flor B. Outpatient versus hospitalization management for uncomplicated diverticulitis: a prospective, multicenter randomized clinical trial (DIVER trial). Ann Surg 2014;259:38-44.

\section{INTESTINAL OBSTRUCTION DUE TO ADHESIONS GUIDELINE SUMMARY}

Small bowel obstruction (SBO) is a common cause for hospital admission and surgical consultation. Although the diagnosis of SBO has become relatively straightforward with the use of CT, there continues to be a debate as to its optimal management. Multiple societies have published guidelines for the diagnosis and management of SBO. This review summarizes and references evidence-based guidelines for diagnosis, treatment and management of SBO. This should be used as a reference guide for surgeons practicing emergency general surgery.

\begin{tabular}{|c|c|c|c|c|}
\hline Grade & $\begin{array}{l}\text { AAST disease } \\
\text { grade }\end{array}$ & Diagnosis & Management & References \\
\hline I & Partial SBO & $\begin{array}{l}\text { CT scan of } \\
\text { abdomen and } \\
\text { pelvis } \\
\text { Water soluble } \\
\text { contrast follow } \\
\text { through to rule } \\
\text { out complete } \\
\text { adhesive } \\
\text { small bowel } \\
\text { obstruction } \\
\text { (ASBO) and } \\
\text { predict need for } \\
\text { surgery }\end{array}$ & $\begin{array}{l}\text { Initial non-operative } \\
\text { management. } \\
\text { Water-soluble contrast } \\
\text { follow through to rule } \\
\text { out complete ASBO and } \\
\text { predict the need for } \\
\text { surgery. } \\
\text { Surgery recommended } \\
\text { after } 3 \text { days without } \\
\text { resolution. } \\
\text { Patients with SBO } \\
\text { should generally be } \\
\text { admitted to a surgical } \\
\text { service }\end{array}$ & 123456 \\
\hline II & $\begin{array}{l}\text { Complete } \\
\text { SBO; bowel } \\
\text { viable and not } \\
\text { compromised }\end{array}$ & $\begin{array}{l}\text { CT scan of } \\
\text { abdomen and } \\
\text { pelvis } \\
\text { Water soluble } \\
\text { contrast follow } \\
\text { through to rule } \\
\text { out complete } \\
\text { ASBO and } \\
\text { predict need for } \\
\text { surgery }\end{array}$ & $\begin{array}{l}\text { Initial non-operative } \\
\text { management. } \\
\text { Water-soluble contrast } \\
\text { follow through to rule } \\
\text { out complete ASBO and } \\
\text { predict the need for } \\
\text { surgery. } \\
\text { Surgery recommended } \\
\text { after } 3 \text { days without } \\
\text { resolution. } \\
\text { Patients with SBO } \\
\text { should generally be } \\
\text { admitted to a surgical } \\
\text { service }\end{array}$ & 123456 \\
\hline III & $\begin{array}{l}\text { Complete } \\
\text { SBO with } \\
\text { compromised } \\
\text { but viable } \\
\text { bowel }\end{array}$ & $\begin{array}{l}\text { CT scan of } \\
\text { abdomen and } \\
\text { pelvis } \\
\text { Water soluble } \\
\text { contrast follow } \\
\text { through to rule } \\
\text { out complete } \\
\text { ASBO and } \\
\text { predict need for } \\
\text { surgery }\end{array}$ & $\begin{array}{l}\text { Operative management. } \\
\text { Open surgery is } \\
\text { preferred method. } \\
\text { Laparoscopic approach } \\
\text { can be attempted in } \\
\text { select cases. }\end{array}$ & 123456 \\
\hline
\end{tabular}

\begin{tabular}{|c|c|c|c|c|}
\hline Grade & $\begin{array}{l}\text { AAST disease } \\
\text { grade }\end{array}$ & Diagnosis & Management & References \\
\hline IV & $\begin{array}{l}\text { Complete SBO } \\
\text { with non- } \\
\text { viable bowel } \\
\text { or perforation } \\
\text { with localized } \\
\text { spillage }\end{array}$ & $\begin{array}{l}\text { CT scan of } \\
\text { abdomen and } \\
\text { pelvis }\end{array}$ & $\begin{array}{l}\text { Operative management. } \\
\text { Open surgery is } \\
\text { preferred method. } \\
\text { Laparoscopic approach } \\
\text { can be attempted in } \\
\text { select cases. } \\
\text { Patients with SBO } \\
\text { should generally be } \\
\text { admitted to a surgical } \\
\text { service. }\end{array}$ & 列 \\
\hline V & $\begin{array}{l}\text { Small bowel } \\
\text { perforation } \\
\text { with diffused } \\
\text { peritoneal } \\
\text { contamination }\end{array}$ & $\begin{array}{l}\text { CT scan of } \\
\text { abdomen and } \\
\text { pelvis }\end{array}$ & $\begin{array}{l}\text { Operative management. } \\
\text { Open surgery is } \\
\text { preferred method. } \\
\text { Laparoscopic approach } \\
\text { can be attempted in } \\
\text { select cases. } \\
\text { Patients with SBO } \\
\text { should generally be } \\
\text { admitted to a surgical } \\
\text { service. }\end{array}$ & 123456 \\
\hline
\end{tabular}

\section{KEY POINTS}

Radiographs have relatively limited use for the imaging confirmation and characterization of an obstruction. Patients with a strong clinical suspicion for ASBO, immediate cross-sectional imaging with CT should be considered. ${ }^{1}$ CT scan has proven to be highly diagnostic in ASBO and is the diagnostic test of choice. ${ }^{1,2}$ MRI is ideal for children and pregnant patients with known or suspected SBO, as well as younger patients with repetitive episodes of obstruction. ${ }^{1}$ If intermittent, recurrent, or low-grade SBO is a primary concern, an enteroclysis is likely the next best test. ${ }^{1}$

Water-Soluble-Contrast-Medium such as Gastrografin is safe and has a definite role in diagnosis (for predicting the resolution or need for surgery) and therapy (for reducing the operative rate, shortening time to resolution, hospital stay). ${ }^{1,-6}$ The unique ability of Gastrografin to draw water into the bowel lumen expedites resolution of partial obstructions. Contrast in the colon on abdominal X-ray within 24 hours of its administration predicts resolution of ASBO..$^{3-6}$ If not obtained at admission, water-soluble contrast studies should be considered in patients who do not clinically resolve after 48 hours for both diagnostic and potential therapeutic purposes.

Patients with evidence of generalized peritonitis or other clinical deterioration (fever, leukocytosis, tachycardia, metabolic acidosis, continuous pain) should undergo timely exploration. The remainder of patients can safely undergo initial non-operative management for both partial and complete SBO. The goal is to immediately identify strangulation and need for urgent operative intervention using a combination of clinical signs and CT findings. Surgery is recommended after 3 days without resolution (but less than 5 days). . $^{3-5}$

Laparoscopy is safe and feasible in the hands of experienced laparoscopic surgeons and in selected patients. ${ }^{4,5}$

Patients with SBO admitted to a surgical service have shorter length of stay, less hospital charges, shorter time to surgery, and lower mortality than patients admitted to a medical service. ${ }^{4}$

Hyaluronic acid-carboxycellulose membrane and icodextrin are proven to reduce adhesions but have not proven to reduce the need for surgery. ${ }^{3}$

\section{AREAS FOR ONGOING RESEARCH}

The role of surgical techniques and biomaterials that can prevent ASBO and reduce the need for surgical intervention are 
topics that warrant further research. Adhesions quantification and scoring is a promising tool for further research that could help standardization and allow for more accurate analysis of ASBO.

\section{REFERENCES}

1. Ros PR, Huprich JE. ACR appropriateness criteria on suspected small-bowel obstruction. J Am Coll Radiol 2006;3:838-41.

2. Rocha FG, Theman TA, Matros E, Ledbetter SM, Zinner MJ, Ferzoco SJ. Nonoperative management of patients with a diagnosis of high-grade small bowel obstruction by computed tomography. Arch Surg 2009;144:1000-4.

3. Di Saverio S, Coccolini F, Galati M, Smerieri N, Biffl WL, Ansaloni L, Tugnoli G, Velmahos GC, Sartelli M, Bendinelli C, et al. Bologna guidelines for diagnosis and management of adhesive small bowel obstruction (ASBO): 2013 update of the evidence-based guidelines from the world society of emergency surgery ASBO Working Group. World $J$ Emerg Surg 2013;8:42.

4. Maung AA, Johnson DC, Piper GL, Barbosa RR, Rowell SE, Bokhari F, Collins JN, Gordon $J R, R a J H$, Kerwin AJ, et al. Evaluation and management of small-bowel obstruction: an eastern association for the surgery of trauma practice management guideline. J Trauma Acute Care Surg 2012:73(5 Suppl 4):S362-9.

5. Azagury D, Liu RC, Morgan A, Spain DA. Small bowel obstruction: a practical step-bystep evidence-based approach to evaluation, decision making, and management. J Trauma Acute Care Surg 2015;79:661-8.

6. Abbas S, Bissett IP, Parry BR. Oral water soluble contrast for the management of adhesive small bowel obstruction. Cochrane Database Syst Rev 2007(3):CD004651.

\section{ACUTE PANCREATITIS MANAGEMENT GUIDELINES SUMMARY}

Acute pancreatitis is one of the most common diseases of the gastrointestinal tract and its incidence may be increasing. It is the most common discharge diagnosis for patients hospitalized for a gastrointestinal disease. ${ }^{4}$ Changes in approach to acute pancreatitis have occurred during the last two decades. These changes were primarily driven by the development of the Atlanta classification for disease severity and the recognition of the early and later phases of disease. The early phase being a period of systemic inflammation of variable severity and the later phase being marked by local complications. ${ }^{4}$ There are multiple published guidelines related to acute pancreatitis. Most of the guidelines focus on the areas of diagnosis, early management, indications for endoscopic procedures and indications for surgical procedures. This review highlights the American Association for the Surgery of Trauma (AAST) grade specific management recommendations for surgeons engaged in the care of these patients. This brief report summarizes guidelines published on the topic of acute pancreatitis until May 30, 2017. Only guidelines with rigorous, reproducible methodologies were selected for this report.

\begin{tabular}{|c|c|c|c|}
\hline AAST grade & Description & Management & References \\
\hline I & $\begin{array}{l}\text { Acute edematous } \\
\text { pancreatitis }\end{array}$ & $\begin{array}{l}\text { Diagnosis by serum markers. } \\
\text { Supportive management and } \\
\text { enteral nutrition as tolerated. } \\
\text { Cholecystectomy at index } \\
\text { admission if gallstones present. } \\
\text { Antibiotics not indicated. } \\
\text { If concomitant cholangitis } \\
\text { is present early ERCP } \\
\text { should be performed. For } \\
\text { choledocholithiasis, without } \\
\text { cholangitis ERCP can be } \\
\text { delayed for } 72 \text { hours. }\end{array}$ & 1234 \\
\hline II & $\begin{array}{l}\text { Pancreatic } \\
\text { phlegmon or } \\
\text { peripancreatic } \\
\text { fluid collection or } \\
\text { hemorrhage }\end{array}$ & $\begin{array}{l}\text { Same as grade I plus CT } \\
\text { scanning at least } 72 \text { hours } \\
\text { after symptom onset. }\end{array}$ & 1234 \\
\hline
\end{tabular}

\begin{tabular}{|c|c|c|c|}
\hline AAST grade & Description & Management & References \\
\hline III & $\begin{array}{l}\text { Sterile pancreatic } \\
\text { necrosis }\end{array}$ & $\begin{array}{l}\text { Same as grade II disease } \\
\text { Management in a monitored } \\
\text { setting (intensive care unit) } \\
\text { Parenteral nutrition for those } \\
\text { failing enteral nutrition. }\end{array}$ & 1234 \\
\hline IV & $\begin{array}{l}\text { Infected pancreatic } \\
\text { necrosis or abscess }\end{array}$ & $\begin{array}{l}\text { Same as grade III disease. } \\
\text { Antibiotics for suspected } \\
\text { infection. } \\
\text { Consider percutaneous } \\
\text { sampling or drainage } \\
\text { Necrosectomy delayed at least } \\
14 \text { days after symptom onset } \\
\text { Necrosectomy technique } \\
\text { guided by local expertise. } \\
\text { Open necrosectomy should be } \\
\text { avoided }\end{array}$ & 12345 \\
\hline V & $\begin{array}{l}\text { Extrapancreatic } \\
\text { extension of } \\
\text { pancreatic necrosis } \\
\text { involving adjacent } \\
\text { organs, such as } \\
\text { colonic necrosis }\end{array}$ & Same as grade IV disease. & 12345 \\
\hline
\end{tabular}

\section{KEY POINTS}

There is a lack of well-done clinical trials in acute pancreatitis that has led to variability in practice within institutions, between institutions and across continents. Therefore, recommendations must be tailored to the clinical situation and the patient being treated and do not represent a standard of care.

The diagnosis of pancreatitis is made when amylase and lipase elevations reach three times the upper limit of normal without renal failure. Abdominal ultrasound should always be obtained to assess for the presence of gallstones and the size of the common bile duct. However, confirmatory CT imaging should be reserved for more severe disease and should be performed after at least 72 hours of symptoms. ${ }^{1}$ Magnetic resonance cholangiopancreatography (MRCP) or endoscopic ultrasound (EUS) are only indicated if the common bile duct is dilated, liver enzymes are elevated in an obstructive pattern or common bile duct stones are highly suspected for another reason..$^{2,4}$ If the patient is over 40 , neoplastic causes should also be considered.

Supportive care including aggressive fluid resuscitation, correction of electrolytes and pain control should be provided. Aggressive fluid resuscitation should be with lactated ringers and occur during the first 12-24 hours in patients who have no contraindications to significant fluid loading. ${ }^{2,4}$ In the event of concomitant cholangitis, urgent (within 24 hours) endoscopic retrograde cholangipancreatography (ERCP) should be performed. ERCP should also be performed if common bile duct obstruction without cholangitis is suspected; however, in this case, it can be delayed up to 72 hours. ${ }^{1}$ If ERCP is performed, pancreatic duct stents or postprocedural rectal non-steroidal anti-inflammatories should be used in patients at high risk for postprocedural pancreatitis. ${ }^{4}$ The ongoing severity of disease should be assessed with daily C-reactive protein and Acute Physiology and Chronic Health Evaluation-II score for the first 72 hours. $^{2}$

Optimal nutritional management and antibiotic treatment in acute pancreatitis remains somewhat controversial. In lower grades of pancreatitis, patients should take a diet as tolerated. If patients are intolerant of oral feeding, a nasojejunal tube is preferred over parenteral nutrition provided tube feeding can be tolerated. ${ }^{2,3}$ Recommendations for antibiotics in pancreatitis have varied over time. Currently, antibiotics are only 
recommended in the case of strongly suspected infection. Antibiotics that penetrate the pancreatic parenchyma should be used in cases of infected pancreatic necrosis.

Peripancreatic fluid collections management is based mostly on large retrospective studies. The main indication for intervention in pancreatic necrosis is infected pancreatic necrosis and clinical deterioration. However, sampling of fluid or necrosis should only be performed if infection is strongly suspected. ${ }^{2}$ Intervention may also be indicated for persistent symptoms with sterile necrosis that has been present for at least 8 weeks. A step-up approach with initial image guided or endoscopic drainage should be used for infected pancreatic necrosis. ${ }^{2}$ Surgical intervention in these cases should be delayed as long as possible and ideally for at least 4 weeks after onset of symptoms to allow the collection to become walled off. ${ }^{3}$ Pseudocysts should only be drained if symptomatic or enlarging ${ }^{2}$.

Cholecystectomy on the index admission is indicated in mild gallstone pancreatitis when symptoms resolve. In patients with peripancreatic fluid collections, cholecystectomy should be delayed until resolution or 6 weeks, whichever is first. ${ }^{5}$ If cholecystectomy is contraindicated, sphicterotomy should be considered. ${ }^{5}$ In the case of multiple episodes of pancreatitis without a clear etiology, additional imaging including EUS or secretin-stimulated MRCP should be performed. ${ }^{3}$

\section{Areas of ongoing research}

Theare are many controversies that remain with respect to acute pancreatitis from presentation to long-term follow-up. Although criteria to diagnose acute pancreatitis and assign a severity on presentation are firmly established, prediction of disease severity during the subsequent days has met with only limited success. Additional research in this area is important as the progress of disease is highly variable and predicting disease severity will allow for more directed use of resources.

Despite strong agreement on the need to delay CT scanning for acute pancreatitis until 72-96 hours after the onset of symptoms, there is only low-quality evidence supporting this practice. There is widespread use of MRCP and EUS; however, the evidence for their use is also minimal. Studies that more firmly establish the role and timing of imaging in pancreatitis are essential. Current therapeutic interventions in acute pancreatitis are also poorly supported. There is, however, reasonably good evidence for withholding intravenous antibiotics to prevent infectious complications of acute pancreatitis. Selective gut decontamination and probiotic administration also remain controversial but may have a role if future studies demonstrate value. Despite strong agreement that enteral nutrition is superior to parenteral nutrition and that nasogastric feeding is equivalent to nasojejunal feeding, there is less agreement for the timing of feeding patients with acute pancreatitis and the type of feeding. Additionally, despite the strong agreement, the evidence for the superiority of enteral feeding is lacking.

Several uncertainties in the procedural management of acute pancreatitis also exist. Although there are relatively well-established indications for ERCP, the timing of ERCP in patients with concomitant pancreatitis and common bile duct obstruction and/or cholangitis has not been firmly established. There is likely benefit to early performance of ERCP when cholangitis is present, however, how early is unclear. There are insufficient data to make a recommendation regarding the method and exact timing of pancreatic necrosectomy for infected pancreatic necrosis. Similarly, there are insufficient data to recommend an initial procedure for draining infected pancreatic necrosis.

Other uncertainties also require further clarification. There is insufficient evidence to make recommendations regarding the evaluation of multiple episodes of idiopathic pancreatitis. Especially, as this pertains to cholecystectomy. There are insufficient data to recommend strongly for or against endoscopic sphincterotomy in patients with pancreatitis and gallstones and who are poor surgical candidates. Outcomes of acute pancreatitis have not improved significantly during the last decade; however, standardizing care by answering these important questions has the greatest immediate potential to improve outcomes.

\section{REFERENCES}

1. American Gastroenterological Association (AGA) Institute on "Management of Acute Pancreatits" Clinical Practice and Economics Committee. AGA Institute governing board. AGA Institute medical position statement on acute pancreatitis. Gastroenterology 2007:2019--21.

2. Greenberg JA, Hsu J, Bawazeer M, Marshall J, Friedrich JO, Nathens A, Coburn N, May GR, Pearsall E, McLeod RS. Clinical practice guideline: management of acute pancreatitis. Can J Surg 2016;59:128-40.

3. Working Group IAP/APA Acute Pancreatitis Guidelines. IAP/APA evidence-based guidelines for the management of acute pancreatitis. Pancreatology 2013;13(4 Suppl 2):e1-15.

4. Tenner S, Baillie J, DeWitt J, Vege SS. American College of gastroenterology guideline: management of acute pancreatitis. Am J Gastroenterol 2013;108:1400-15.

5. UhI W, Warshaw A, Imrie C, Bassi C, McKay CJ, Lankisch PG, Carter R, Magno ED, Banks PA, Whitcomb DC, et al. IAP guidelines for the surgical management of acute pancreatitis. Pancreatology 2002;2:565-73. 